\title{
The utilization possibility of waste lignite as a raw material in the process of obtaining humic acids preparations
}

\author{
Krystyna Hoffmann*, Marta Huculak-Mączka \\ Wroctaw University of Technology, Chemistry Department, Intitute of Inorganic Technology and Mineral Fertilizers, \\ ul. Wybrzeże Wyspiańskiego 27, 50-372 Wroctaw, Poland \\ "Corresponding author: krystyna.hoffmann@pwrwroc.pl
}

\begin{abstract}
In the light of environmental law utilization lignite waste in non-energy sectors of the economy is a rational way to manage them. Lignite due to the lower degree of coalification and calorific value as well as a high content of humic substances becomes a valuable component of fertilizer. The paper presents the possibility of using lignite waste as a raw material in the process of obtaining humic acids with $0.1 \mathrm{M} \mathrm{NaOH}$. The idea of the process combines production, environmental and economic purposes. After the extraction process of humic acids and considering the possibility of using waste formed during the process, were carried out a number of studies to assist in choosing the best solution to its management.
\end{abstract}

Keywords: brown coals, humic acids, extraction, alkaline waste

\section{INTRODUCTION}

The problem of the correct proceeding of wastes, their economic utilization and protection against their harmful effects belong to the most important environmental issues. Waste management, which are the result of civilization development is also an important socio-economic problem. It requires both the relevant legal norms and effective technological solutions.

To determine the type of generated wastes and the possibilities of their utilization without a negative impact on the environment, wastes classification is needed, taking into account inter alia their genesis, properties, ecological harmfulness and utility. There are many division criteria of wastes but the most important are these which are characterized by physicochemical, biological, technological and economic properties such as the source, the criterion of raw materials, physical state, chemical composition and toxicity.

According to the Act on Waste of 27 September 2001, one of the easiest way of wastes classification is their division according to the source of origin and the possible environmental risks. Among them a group of industrial waste is distinguished ${ }^{\mathbf{1}, \mathbf{2}}$.

The diversity of industrial activity generates a considerable amount of various wastes. Intensive industrial activity and a simultaneous increase in demand for food cause a systematic decrease in agricultural production area. An important current issue is thus to increase agricultural productivity in connection with rational utilization of wastes generated in industry.

An alternative way of the utilization of by-products and wastes from various departments and sectors of the economy is their use for remediation, soil conditioners and fertilization. For this kind of management substances and compounds containing in their composition organic matter and nutrients are especially suitable. However, in most cases the waste before using must be subjected to various physicochemical processes. The aim of this activity is the hygienisation and elimination of harmful substances and compounds. Before agricultural utilization of wastes, particularly unconventional, there is a necessity to control their composition. In addition, the fertilizer market demands and technological progress tend to use wastes in the best shape and form allowing for easy, safe for humans and the environment using, as well as increasing the efficiency of the impact on soil and plants ${ }^{1-6}$.

Among the industrial wastes in Poland a large part of them constitute waste materials generated in the process of extraction, enrichment and processing of minerals and whose main source is mining and energy industry. In agriculture, due to the amount and favorable properties is the utilization of waste lignite. They are the subject of many studies, which consequently allow defining their agricultural usefulness and utilization in a wide range of fertilizer products. For agricultural advantages of lignite organic matter content, including its key component humic acids is primarily responsible 1,7-12 $^{\text {. }}$

\section{Lignite - the possibility of utilization in agriculture}

Brown coals in terms of biochemical processing degree constitute a transitional stage between peat and coal. The technical and chemical parameters of lignite determine its position in the coalification process chain. The content of carbon in lignite as solid fuel determines the amount of heat generated during its combustion (heat of combustion). The largest percentage of carbon is in the coal (up to $97 \%$ of combustible mass), less in the lignite (less than $80 \%$ of combustible mass), wood and peat (more than $50 \%$ of combustible mass). The type of plant matter from which lignite is formed and the conditions of its formation greatly impact its characteristics and properties. Taking into consideration the degree of coalification and the physicochemical properties, including primarily the moisture content and external appearance of lignite, lignite can be classified into the following groups:

- soft lignite - low degree of coalification, basic petrographic variations thereof are earthy and shale of lignite, which are characterized by a moisture content from 70 to $40 \mathrm{wt} \%$, a color pale-brown or brown-black and poorly concise structure.

- hard lignite is characterized by a high degree of coalification, in which the moisture content is in the range of 
40-20 wt \%, concise structure, high mechanical strength, color from brown to black, and varying degrees of gloss, under which it is divided into matte and glossy lignite.

- xylite lignite, which is often classified as soft sort of the lignite, is characterized by a well-preserved wood structure $^{7-9}$.

In the area of Poland the deposits of xylite and soft lignite, especially the earthy sort of them, prevail. The deposits of lignite originate mainly from the period of the Lower Jurassic, Upper Cretaceous and Tertiary, whose average calorific value ranges from 6.3 to 10.9 $\mathrm{MJ} / \mathrm{kg}$. Lignite in the dominant degree is used for energy purposes, however in the age of rational utilization of non-renewable resources, technological progress leads to the focus on lignite utilization outside the energy sector such as agriculture or chemistry. For agricultural purpose brown coals with low energy value, which are often a waste during raw material exploitation, are used. Their application as a rich source of organic matter and minerals is also a rational way of managing them ${ }^{13-17}$.

As solid fuel lignite consists of a combustible mass (combustible substance) containing, except pure carbon (C), a number of chemical compounds of carbon with hydrogen $\left(\mathrm{H}_{2}\right)$, oxygen $\left(\mathrm{O}_{2}\right)$, nitrogen $\left(\mathrm{N}_{2}\right)$ and sulfur (S) as well as the so-called ballast. The ballast includes ash and water. The content of non-combustible mineral substance (ash) and its composition adversely affect the quality lignite as a fuel (heat of combustion) and its suitability for energy purposes. Combustion of lignite in power stations causes the formation of large amounts of heaps of fly ash, which are stored in its vicinity. The waste stored in this way is heavy for the environment. Due to its composition, however it may be a beneficial component of fertilizer. Ashes from lignite are a valuable source of $\mathrm{Ca}, \mathrm{Mg}, \mathrm{Fe}, \mathrm{B}, \mathrm{Na}, \mathrm{Mo}, \mathrm{Cu}, \mathrm{Zn}, \mathrm{P}, \mathrm{K}$ and are currently used in agriculture 9,13-15,18. $^{\text {. }}$

These features which indicate unsuitability of lignite as a fuel are simultaneously beneficial parameters that provide the possibility of lignite utilization in agriculture. And conversely, these features that determine the energy value of lignite are often unfavorable from the fertilizing point of view.

Due to the lower degree of coalification and calorific value as well as high content of humic substances, lignite is becoming a valuable component of fertilizer. Humic acids in lignite are also a component of soil organic matter and their beneficial complexing and sorption properties is a factor in favor of the desirability of their use both in agriculture and other industries ${ }^{19-23}$.

Beneficial for agriculture properties of lignite and development widely understood of the fertilizer industry create a wide spectrum of its possible ways of using. The fertilizing properties of lignite have long been known, however large market requirements and ecological conditions contribute to the search for new and more innovative technologies to enable effective utilization of such material in agriculture. To meet the needs of fertilizer market and to improve the quality of fertilizers it seems reasonable to introduce the product in the form of preparations of humic acids obtained from lignite $\mathbf{1 1 , 1 6 , 2 4}^{\text {. }}$

The idea of obtaining humic acids from the national deposits of lignite tends to reconcile economic deve- lopment with rational waste management of the mining industry and global balance of ecosystems ${ }^{\mathbf{1 , 2 5}}$.

\section{The idea of the preparation process of humic acids from lignite}

A determining factor influencing the degree of humic acids extraction from lignite and their physicochemical properties is a selection of raw material and an alkaline agent.

The concept of obtaining humic acids involves two stages. In the first step lignite is subjected to a chemical extraction process using alkali factor to obtain an extract of humic acids (fulvic and humic). In a second stage precipitation of humic acids from the extract by acidification of the environment takes place. The process of the preparation of humic acids using an alkaline extraction method is a relatively easy but time consuming way of obtaining them. This method is accompanied by the formation of waste products, primarily the solid ones. These wastes constitute approximately $20 \%$ of the initial amount of raw materials, which were put into the extraction process. In the light of environmental laws in the field of waste management, the aim of this work is to estimate the possibility of using waste lignite as a raw material in the process of obtaining humic acids and an attempt to assess the validity of the use of alkaline extraction with regard to waste management - post-

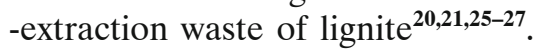

\section{EXPERIMENTAL}

The range of the research presented in the work can be divided into three stages. The first step involves chemical and physicochemical characteristics of lignite for its possible use as a raw material for humic acids preparation. The next stage concerns the process of obtaining humic acids from lignite by using the alkaline extraction method. After the extraction process of humic acids and considering the possibility of using the alkaline waste formed during the process, the number of studies was made supporting the choice of the best solution of its utilization.

\section{MATERIALS AND METHODS}

\section{Characteristics of lignite}

The suitability of lignite as an optimal source of humic acids indicates mainly the content of humic substances and minerals. For this purpose brown coals from 4 major deposits of this raw material in Poland were examined. Brown coals from the basin of Bełchatów, Turów, Konin and Sieniawa Lubuska were examined. For the chemical and physicochemical characteristics of the examined brown coals samples in air-dry state, crushed to a grain size below $0.5 \mathrm{~mm}$ were used.

As a part of physicochemical characteristic of national brown coals, in the samples of raw material the content of organic carbon, phosphorus, total nitrogen, moisture as well as the value of $\mathrm{pH}$ in water and $\mathrm{KCl}$ solution, were determined. Samples of brown coals were also subjected to multi-elemental analysis. The content of the following elements: $\mathrm{Ca}, \mathrm{Mg}$, $\mathrm{Na}$ was determined using ICP-OES. The analyses were carried out in the Chemical Laboratory 
of Multielemental Analysis accredited by Polish Centre for Accreditation. Moreover, in the samples the heat of combustion (in the analysis state) $\mathrm{Q}^{\mathrm{a}}{ }_{\mathrm{s}}$ was determined and their calorific value (in the working state) $\mathrm{Q}_{\mathrm{i}}^{\mathrm{r} 28-33}$ was calculated.

\section{The extraction process of humic acids from lignite}

On the basis of brown coals analysis, the lignite from Sieniawa Lubuska was selected for further study. The process of alkaline extraction was performed using 0.1 $\mathrm{M} \mathrm{NaOH}$. The weight ratio of lignite to the extraction solution was 1:10. The process was carried out at room temperature, the time of contact and mixing reaction components did not exceed 24 hours.

The alkaline extraction process of humic acids from lignite lies in the fact that lignite is extracted with using the alkaline solution (extrahent), the precipitate (alkaline waste) is separated from the extract and humic acids are precipitated by acidification with $2 \mathrm{M} \mathrm{H}_{2} \mathrm{SO}_{4}$ solution to $\mathrm{pH}$ about 2. Next the precipitated humic acids are separated from the solution and depending on the needs, they are dried and subjected to further processing. A schematic process of obtaining humic acids from lignite is shown in Figure 1. In the process the so-called alkaline waste is formed as a by-product.

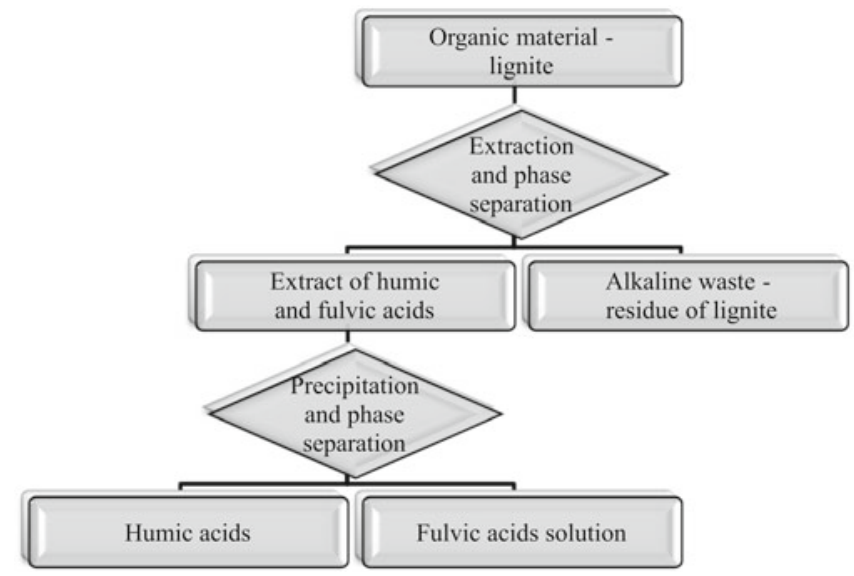

Figure 1. Scheme of humic acids preparation from lignite

Chemical composition, physicochemical and energetic parameters of solid alkaline waste after the extraction of humic acids from lignite with $0.1 \mathrm{M} \mathrm{NaOH}$

The by-product (solid waste) which is accompanied to the extraction process of humic acids from lignite using $0.1 \mathrm{M} \mathrm{NaOH}$ contains primarily organic residue of lignite, minerals and calcium hydroxide. In assessing the post-extraction waste and the possibilities of its utilization the same determinations as in the case of raw brown coals were carried out. Moreover, the content of selected heavy metals was determined and in the framework of a proposal to this waste utilization in the combustion process, it was characterized by determining the following parameters: $\mathrm{W}^{\mathrm{a}}$ - the content of moisture in the analytical state, $\mathrm{W}_{\mathrm{ex}}^{\mathrm{r}}$ - exceeding content of moisture in the working state, $\mathrm{A}^{\mathrm{a}}$ - ash content in the analytical state, $\mathrm{Q}_{\mathrm{s}}^{\mathrm{a}}$ - heat of combustion in the analytical state, $\mathrm{Q}_{\mathrm{i}}^{\mathrm{a}}-$ calorific value in the analytical state and $\mathrm{Q}_{\mathrm{i}}^{\mathrm{r}}-$ calorific value in the working state ${ }^{30-33}$.

\section{RESULTS AND DISCUSSION}

One of the criteria for assessing the possibility of using lignite as a raw material for the preparation of humic acid is its chemical composition, in particular the content of organic matter. The chemical characteristics of the examined brown coals are shown in Table 1 . The high content of organic matter in the examined raw materials is shown by a significant content of organic carbon.

The studies also show that lignite, although to a small extent, is also a source of calcium, magnesium, nitrogen, phosphorus and sodium.

Mineral substances of lignite exist as a separate inorganic material and then their content is random. More often, however, minerals are associated with organic matter of lignite, mainly due to the reactive functional groups of humic acids. The ability of humic substances of lignite to bind metals in the form of salts or complex compounds determine the availability of nutrients for plants.

In the process of determining the possibilities of using lignite for fertilizing purposes, the $\mathrm{pH}$ value has also a huge meaning. All the examined brown coals are characterized by a $\mathrm{pH}$ close to neutral.

The water content in the analytical state of brown coals has rather wide limits and is up to $35 \mathrm{wt} \%$. The moisture of lignite as a fuel is an undesirable feature because of the difficulty of ignition and its calorific value decrease. Due to the agricultural usefulness this parameter contributes to the improvement of water-air conditions of soil and thus has a beneficial effect on plant growth.

According to the literature, the heat of combustion of brown coals containing from 10 to $75 \%$ of the total

Table 1. Characteristics of selected brown coals

\begin{tabular}{|c|c|c|c|c|c|}
\hline \multirow[b]{2}{*}{ No. } & \multirow[b]{2}{*}{ Parameter } & \multicolumn{4}{|c|}{ The origin of lignite } \\
\hline & & Bełchatów & Konin & Turów & $\begin{array}{r}\text { Sieniawa } \\
\text { Lubuska }\end{array}$ \\
\hline 1 & $\mathrm{C}_{\text {org. }}[\mathrm{wt} \%]$ & 52.4 & 58.9 & 46.0 & 65.2 \\
\hline 2 & $\mathrm{~N}[\mathrm{wt} \%]$ & 0.23 & 0.21 & 0.25 & 0.28 \\
\hline 3 & $\mathrm{P}$ [wt \%] & 0.03 & 0.15 & 0.02 & 0.18 \\
\hline 4 & $\mathrm{Ca}$ [wt \%] & 3.30 & 2.50 & 1.11 & 2.04 \\
\hline 5 & $\mathrm{Mg}$ [wt \%] & 0.35 & 0.60 & 0.53 & 0.26 \\
\hline 6 & $\mathrm{Na}$ [wt \%] & 0.20 & 0.18 & 1.56 & 0.22 \\
\hline 7 & $\mathrm{pH}-\mathrm{H}_{2} \mathrm{O}$ & 6.67 & 6.59 & 7.02 & 6.35 \\
\hline 8 & $\mathrm{pH}-\mathrm{KCl}$ & 5.98 & 6.00 & 6.67 & 5.80 \\
\hline 9 & $W^{\mathrm{a}}[w t \%]$ & 26.0 & 36.5 & 8.70 & 24.0 \\
\hline 10 & $Q^{a}[k J / k g]$ & 17376 & 14452 & 25414 & 15932 \\
\hline 11 & $\begin{array}{c}Q_{i}^{r}[M J / k g] \text { calculated on } \\
\text { a sample, whose } W_{t}^{r}=50 \%\end{array}$ & 9.91 & 9.52 & 11.9 & 8.60 \\
\hline
\end{tabular}


moisture is at the level from 6700 to $25000 \mathrm{~kJ} / \mathrm{kg}$. Other sources of literature regarding the classification of brown coals report that the group of energetic brown coals may already include those whose calorific value in the working condition and when the total moisture $-\mathrm{W}_{\mathrm{t}}^{\mathrm{r}}$ $=50 \%$, is above $6.7 \mathrm{MJ} / \mathrm{kg}$. The fuel parameters of the examined brown coals indicate that they belong rather to the low-calorie coals.

The results of physicochemical analysis of the examined brown coals allowed us to select lignite from the deposit of Sieniawa Lubuska as a raw material in the process of obtaining humic acids on a laboratory scale. The main determinant which has influence on the choice of raw material was first of all the high content of organic carbon. The efficiency of humic acids extraction is determined not only by raw material which are extracted but also by the physicochemical parameters of the process. One of the most important is the selection of appropriate extractant. In the extraction process of humic acid an alkaline solution of $0.1 \mathrm{M} \mathrm{NaOH}$ was used.

The process of obtaining humic acids is accompanied by the formation of alkaline waste. Alkaline waste is the main by-product of the direct extraction of humic acids from lignite using the solution of sodium hydroxide. The composition of such waste is partly dependent on the type of the used extractant. Due to the application for the extraction solution of sodium hydroxide (presumably) the main substances in the solid phase, which are part of the waste are: calcium hydroxide, a significant part of lignite organic matter and compounds in trace amounts, which after separation of solid and liquid phases, passed along with a solution to the solid phase.

Taking into consideration the possibility of recycling alkaline waste, a number of studies were carried out. The results systematized and summarized in Tables 2 and 3. To observe and identify changes in the chemical composition and physicochemical properties of lignite before (raw lignite) and after (alkaline waste) alkaline extraction, the results of the analysis of the initial sample are also demonstrated in the tables.

Alkaline waste which was formed after the extraction with sodium hydroxide, contains a significant content of water. The total moisture is about $80 \mathrm{wt} \%$. The ignition loss consists primarily of organic and some inorganic compounds, which decompose during annealing.

The content of organic matter in terms of the quantity of organic carbon in the waste does not exceed $26 \mathrm{wt} \%$.

Table 2. Summary of chemical composition and physicochemical parameters of alkaline waste after extraction of humic acids from lignite (Sieniawa Lubuska) with $0.1 \mathrm{M} \mathrm{NaOH}$

\begin{tabular}{|l|c|c|c|}
\hline \multirow{2}{*}{ No. } & Parameter & \multicolumn{2}{|c|}{ The kind of sample } \\
\cline { 3 - 4 } & & $\begin{array}{c}\text { Alkaline } \\
\text { waste }\end{array}$ & $\begin{array}{c}\text { Lignite } \\
\text { (Sieniawa } \\
\text { Lubuska) }\end{array}$ \\
\hline 1 & $\mathrm{C}_{\text {org }}[\mathrm{wt} \%]$ & 25.4 & 65.2 \\
\hline 2 & $\mathrm{P}[\mathrm{wt} \%]$ & 0.07 & 0.18 \\
\hline 3 & $\mathrm{Ca}[\mathrm{wt} \%]$ & 0.45 & 2.04 \\
\hline 4 & $\mathrm{Mg}[\mathrm{wt} \%]$ & 0.06 & 0.26 \\
\hline 5 & $\mathrm{Na}[\mathrm{wt} \%]$ & 0.66 & 0.22 \\
\hline 6 & $\mathrm{~W}[\mathrm{wt} \%]$ & 80.1 & 25.1 \\
\hline 7 & Loss on ignition [wt \%] & 69.3 & 83.7 \\
\hline 8 & $\mathrm{pH}-\mathrm{H}_{2} \mathrm{O}$ & 9.37 & 6.35 \\
\hline 9 & $\mathrm{pH}-\mathrm{KCl}$ & 8.12 & 5.80 \\
\hline
\end{tabular}

The content of organic carbon in the alkaline waste corresponds mainly with this in humic acids (fulvic and humic) and depends on the ability of the extraction and the nature of the reagent used in the process. The higher content of $\mathrm{C}_{\text {org }}$ in the form of extractable organic compounds, the lower is this content in the waste after the extraction. This relationship provides the possibility of displacement from lignite acidic compounds such as humic compounds which are a source of available forms of nutrients, including organic carbon.

Other components of the waste present in minute quantities, and their average content does not exceed $1 \%$. The content of minerals in alkaline waste is usually lower than that in the input raw material. The decrease of the content of $\mathrm{Ca}$ and $\mathrm{Mg}$ in alkaline waste indicates the validity of the assumption that during the extraction of humic acids from lignite with sodium hydroxide the displacement of base cations associated with organic matter by sodium ions, forming soluble compounds in an alkaline medium, occurs. However, the use of $\mathrm{NaOH}$ as the extracting agent leads to the introduction of the additional quantities of sodium.

Waste after alkaline extraction of humic acids from lignite has alkaline properties. It is evidenced by the $\mathrm{pH}$ value, which in water is 9.37. The $\mathrm{pH}$ of the waste measured in $\mathrm{KCl}$ solution is slightly less and arises from the fact that some $\mathrm{K}^{+}$ions undergo exchange reaction with the least bound $\mathrm{H}^{+}$ions that pass into a solution.

The important information about wastes is also the content of toxic elements. It is one of the criteria used for the qualification of the waste. The content of heavy metals in alkaline waste after the extraction of humic acids from lignite is so small that they can be disregarded in assessing its suitability for agricultural purposes. The average composition of the harmful elements is shown in Table 3.

Table 3. The average composition of heavy elements in the waste after humic acids extraction from lignite (Sieniawa Lubuska) using $0.1 \mathrm{M} \mathrm{NaOH}$

\begin{tabular}{|l|c|c|c|}
\hline \multirow{2}{*}{ No. } & \multirow{2}{*}{$\begin{array}{c}\text { Parameter } \\
{[\mathrm{mg} / \mathrm{kg}]}\end{array}$} & Alkaline waste & $\begin{array}{c}\text { The kind of sample } \\
\text { (Sieniawa } \\
\text { Lubuska) }\end{array}$ \\
\cline { 3 - 4 } & Lead & $<0.25$ & $<2.5$ \\
\hline 1 & Mercury & 0.023 & 0.085 \\
\hline 2 & Nickel & $<0.05$ & $<0.50$ \\
\hline 3 & Copper & 18 & 47 \\
\hline 4 & Chromium & 2.2 & 3.4 \\
\hline 5 & & & \\
\hline
\end{tabular}

Table 4 shows the results regarding the fuel properties of alkaline waste after the extraction process with 0.1 $\mathrm{M} \mathrm{NaOH}$. For comparison, measurements were also performed for a sample of the raw lignite.

The quality of the post-extraction waste with regard to energy can be assessed by referring to the definition of combustion heat and calorific value. The composition and parameters of the examined waste in the working state directly and best characterized the possibility of their management by combustion. The average calorific value $\left(\mathrm{Q}_{\mathrm{i}}^{\mathrm{r}}\right)$ of polish brown coals in the working state oscillates between $6.7-10.9 \mathrm{MJ} / \mathrm{kg}$. The calorific value of the examined waste does not fall within this range. Alkaline waste as a direct by-product in the process of 
Table 4. Fuel properties of alkaline waste after humic acids extraction from lignite (Sieniawa Lubuska) using $0.1 \mathrm{M} \mathrm{NaOH}$

\begin{tabular}{|c|c|c|c|c|}
\hline \multirow[b]{2}{*}{ No. } & \multirow{2}{*}{\multicolumn{2}{|c|}{ Parameter }} & \multicolumn{2}{|c|}{ The kind of sample } \\
\hline & & & \multirow{2}{*}{$\begin{array}{c}\text { Alkaline waste } \\
12.0\end{array}$} & \multirow{2}{*}{$\begin{array}{c}\text { Lignite } \\
\text { (Sieniawa Lubuska) } \\
24.0\end{array}$} \\
\hline \multirow{2}{*}{1} & \multirow{2}{*}{ Moisture [wt \%] } & analytical, $\mathrm{W}^{\mathrm{a}}$ & & \\
\hline & & exceeding, $W_{e x}^{r}$ & 77.4 & 1.5 \\
\hline 2 & \multicolumn{2}{|c|}{$\begin{array}{l}\text { Ash in the analytical state, } \\
\qquad A^{a}[w t \%]\end{array}$} & 17.3 & Not determined \\
\hline 3 & \multicolumn{2}{|c|}{$\begin{array}{l}\text { Heat of combustion in analytical state, } \\
\qquad Q^{a}{ }_{s}[\mathrm{~kJ} / \mathrm{kg}]\end{array}$} & 19180 & 15932 \\
\hline 4 & \multicolumn{2}{|c|}{$\begin{array}{l}\text { Calorific value in the analytical state, } \\
\qquad Q^{\mathrm{a}}{ }_{i}[\mathrm{~kJ} / \mathrm{kg}]\end{array}$} & 18031 & 14424 \\
\hline 5 & \multicolumn{2}{|c|}{$\begin{array}{l}\text { Calorific value in the working state, } \\
\qquad Q_{i}^{r}[\mathrm{~kJ} / \mathrm{kg}]\end{array}$} & 2676 & 14171 \\
\hline
\end{tabular}

obtaining humic acid contains considerable amounts of water. High content of moisture in the samples has a negative impact on the ignition and reduces their calorific value. Disposal of waste in the thermal way requires additional processing of the material or supplying additional fuel to maintain the combustion process. Modification processes of waste focus mainly on the transformation to remove the excess moisture from the potential energy materials. They are therefore: thickening, dewatering and drying the waste, leading to increased efficiency and profitability of the combustion process. The validity of using this type of treatment confirms the calorific value in the analytical state. For waste formed during alkaline extraction of humic acids from lignite by using $0.1 \mathrm{M}$ $\mathrm{NaOH}$ this parameter reaches the value of $18031 \mathrm{~kJ} /$ $\mathrm{kg}$ and is comparable or even greater than that in the case of raw lignite.

In addition, the content and composition of the non-combustible mineral substance (ash) affect the efficiency of waste combustion process and its suitability for energy purposes. In the case of alkaline waste it is equal to $17.3 \mathrm{wt} \%$. This value is in the range of the technological parameters of typical brown coals, which establish the ash content in the energetic materials from 8 to $30 \%$.

\section{SUMMARY AND CONCLUSIONS}

Rational management of mining waste is one of the main environmental issues. In the age of rational and efficient utilization of non-renewable resources, brown coal industry should also become part of other sectors of the economy, including the fertilizer industry. These features that indicate unsuitability of lignite as a fuel are simultaneously the beneficial parameters that provide the possibility of using of lignite in agriculture. Brown coals with a low energy value, which often are a waste in mines, can be successfully used in agriculture as a fertilizer component.

The number of physicochemical properties of humic substances, the changing trends on the fertilizer market, innovation factor and ecological conditions contributed recently to the increasing of interest in humic acids. The suitability of lignite as a raw material in the process of obtaining such a valuable humic acids is provided primarily by the content of $\mathrm{C}_{\text {org }}$ and to a lesser extent, the contents of minerals. A determining factor influencing the degree of humic acids extraction from lignite is except the raw material the choice of extractant.

The idea of obtaining humic acids from the national lignite by using $0.1 \mathrm{M} \mathrm{NaOH}$, according to the Principles for Sustainable Development includes productive, economic, social and ecological purposes. The introduction of this type of solution, is however associated with the formation of alkaline waste. The chemical composition, physicochemical parameters and fuel properties of post-extraction waste indicate the possibility of its recycle in thermal way. The condition for the proper conduct of the post-extraction waste combustion process is its pretreatment. The processes of thickening, dewatering and drying are focused mainly on removing the water contained in the waste. Treatment of the post-extraction waste will allow its effective and profitable combustion.

\section{LITERATURE CITED}

1. Rosik-Dulewska, Cz., (2008). The basis for waste management, PWN, Warszawa (in Polish).

2. Regulation of the Minister of the Environment of 27 September 2001 on the catalogue of waste (J. of L. 112, item 1206) (in Polish).

3. Rosik-Dulewska, Cz., Robak, J. \& Głowala, K. (2007). Granulated organic and mineral fertilizers: Technology and utility properties, Pol. J. Chem. Tech. 9/4, 36-39. DOI: 10.2478/ v10026-007-0085-9.

4. Hoffmann, J. \& Radosiński, E. (2007). Environmental management concepts supported by information technology, Pol. J Chem. Tech., 4, 8-13. DOI: 10.2478/v10026-007-0080-1.

5. Rosik-Dulewska, Cz., Głowala, K., Karwaczyńska, U. \& Robak, J. (2008). Elution of heavy metals from granulates produced from minicipal sewage deposits and fly-ash of hard and Brown coal in the aspect of recycling for fertilization purposes. Arch. Environ. Prot., 34/2, 63-71.

6. Hoffmann, K. \& Hoffmann, J. (2007). The utilization of peat, lignite and industrial wastes in the production of mineral-organic fertilizers, Am. J. Agric. Biol. Sci., 2/4, 254 259. http://www.scipub.org/scipub/journals.php. DOI: 10.3844/ ajabssp.2007.254.259.

7. Chudek, M., Hycnar, J., Janiczek, S. \& Plewa, F. (1999). Brown coal - utilization of accompanying raw materials and energetic waste, Wyd. Politechniki Śląskiej, Gliwice (in Polish).

8. Kalembasa, S. \& Tengler, S. (2004). The role of lignite in the fertilization and environmental protection, Monografie nr 52, Wyd. Akademii Podlaskiej, Siedlce (in Polish).

9. Maciejewska, A. (1998). Lignite as a source of organic matter and its influence on soil properties, Oficyna Wydawnicza Politechniki Warszawskiej, Warszawa (in Polish).

10. Bereśniewicz, A. \& Nowosielski, O. (1976). The possibility of agricultural use of lignite, Zesz. Probl. Post. Nauk Rol., 1, 69-84 (in Polish).

11. Nowosielski, O. (1995). Lignite as a base and fertilizer and raw material for production of bases and fertilizers. Węg. Brunat., 4, 87-92 (in Polish). 
12. Maciejewska, A. \& Kwiatkowska, J. (2002). The use of preparations from lignite to management of post-mining land, Acta Agroph., 73, 243-250 (in Polish).

13. Nowak, J. \& Kudełko, J. (2008). The use of lignite in terms of application manufacturing technology of other energy carriers, Gosp. Sur. Min., 24/4, 259-271 (in Polish).

14. Kasiński, J., Mazurek, S. \& Piwocki, M. (2006). Evaluation and ranking of lignite deposits in Poland. Państwowy Instytut Geologiczny, Warszawa (in Polish).

15. Kasztelewicz Z. (2008). Lignite resources in Poland and the prospects for its use, Polit. Energ., 11/1, 181-200 (in Polish).

16. Maciejewska, A. (1998). Directions for further research on the use of lignite in agriculture and environmental protection, Zesz. Probl. Post. Nauk Rol., 455, 223-232 (in Polish).

17. Grzelak, A. (1993). Utilization possibilities of lignite and accompanying raw materials in agriculture and ecology, Gór. Odkryw. XXXV, 3-4, 51-65 (in Polish).

18. Brożyna, M., Rosik-Dulewska, Cz., Dulewski, J. \& Król, R. (1999). Technical and legal aspects of fly-ash utilization in coal mines in Poland. Proccedings of the International Symposium on Beneficiation, Aglomeration and Environment (ISBAN-99). Bhubaneswar January, 411-416.

19. Mazur, T., Wojtas, A. \& Mazur, Z. (1998). Agricultural value of mineral-organic fertilizers produced on the basis of lignite, Zesz. Probl. Post. Nauk Rol., 455, 141-147 (in Polish).

20. Hoffmann, K. \& Huculak-Mączka, M., (2011). Evaluation of sorption properties of humic acids as a factor in determining the possibility of their use for fertilizer purpose, Przem. Chem., 90/5, 792-795 (in Polish).

21. Stevenson, F., J. (1994). Humus chemistry. Genesis, composition, reactions, John Wiley\&Sons, New York.

22. Huculak-Mączka, M., Hoffmann, K., Skut, J. \& Hoffmann J. (2010). Evaluation of humic substances content in selected raw materials and wastes, Proc. ECOpole, 4/2, 383-387 (in Polish).

23. Huculak-Mączka, M., Hoffmann, K. \& Hoffmann, J. (2009). The use of selected analytical methods to evaluate the the organic matter content in the fertilizer components, Zesz. Probl. Post. Nauk Rol., 537, 145-151 (in Polish).

24. Hoffmann, J. \& Hoffmann, K. (2003). Sustainable development in production of fertilizers, Przem. Chem., 82/8-9, 837-939 (in Polish).

25. Hoffmann, K., Popławski, D., Huculak-Mączka, M. \& Hoffmann, J. (2010). Influence of the fineness on efficiency of obtaining humic acids from lignite, Proc. ECOpole, 4/2, 377-381 (in Polish).

26. Huculak-Mączka, M., Hoffmann, K. \& Hoffmann, J. (2010). Research on the influence of chemical agents on the properties of selected humic substances, Przem. Chem., 89/4, 396-399 (in Polish).

27. Polish Standard PN-Z-15011-3:2001.

28. Polish Standard PN-88/C-87105.

29. Polish Standard PN-Z-15011-3:2001.

30. Polish Standard a PN-Z-93/C-87085.

31. Polish Standard PN-80/G-04511.

32. Polish Standard PN-80/G-04512.

33. Polish Standard PN-81/G-4513. 